\title{
Community's Influence on Igbo Musical Artiste and His Art
}

\author{
Alvan-Ikoku Okwudiri Nwamara \\ Department of Music, Nnamdi Azikiwe University, Awka, Nigeria \\ Email address: \\ ao.nwamara@unizik.edu.ng
}

\section{To cite this article:}

Alvan-Ikoku Okwudiri Nwamara. Community's Influence on Igbo Musical Artiste and His Art. International Journal of Literature and Arts. Vol. 7, No. 1, 2019, pp. 1-8. doi: 10.11648/j.ijla.20190701.11

Received: September 19, 2018; Accepted: October 17, 2018; Published: March 11, 2019

\begin{abstract}
The Igbo traditional concept of "Ohaka: The Community is Supreme," is mostly expressed in Igbo names like; Nwoha/Nwora (Community-Owned Child), Oranekwulu/Ohanekwulu (Community Intercedes/intervenes), Obiora/Obioha (Community-Owned Son), Adaora/Adaoha (Community-Owned Daughter) etc. This indicates value attached to Ora/Oha (Community) in Igbo culture. Musical studies have shown that the Igbo musical artiste does not exist in isolation; rather, he performs in/for his community and is guided by the norms and values of his culture. Most Igbo musicological scholars affirm that some of his works require the community as co-performers while some require collaboration with some gifted members of his community. His musical instruments are approved and often times constructed by members of his community as well as his costumes and other paraphernalia. But in recent times, modernity has not been so friendly to this "Ohaka" concept; hence the promotion of individuality/individualism concepts in various guises within the context of Igbo musical arts performance. Technological advancements on the one hand, try to promote and popularize Igbo musical arts, while on the other hand, dampen the spiritual and socio-cultural essence of the art. Coming from a performer/participant observer's perspective, the author carefully examines the nature of Igbo musical arts in modern times in comparison to ethno-historical viewpoints gathered through review of related literatures. In general, the paper highlights Ohaka in Igbo musical arts with emphasis on the artiste, his art, effects of modernity on the concept and subsequently suggests way forward.
\end{abstract}

Keywords: Igbo, Musical Arts, Community, Musical Artiste, Ohaka

\section{Introduction}

One of the three major ethnic groups in Nigeria is the Igbo. According to Okafor [1], sources of the theories on the origin of the Igbo are traceable to ethnographic background of the Igbo, oral traditions and archaeological findings. ${ }^{1}$ The life style of every traditional Igbo society is most times community centred - they believe so much in communal living. This communitarianism has some effects on all activities evident in Igbo culture-music inclusive. The Igbo musical artiste and his music are, to a great extent influenced by the dos and don'ts of his community. Indigenous Igbo communities are found basically in five South Eastern states of Nigeria - Abia, Anambra, Ebonyi, Enugu and Imo. Forchu [2] informs that Igbos are made up of a collection of independent groups of people who speak the Igbo language and who have minor cultural, dialectical, and social

1 Okafor, R. C. A Study of Igbo Folk Songs. Enugu: Academic Publishing Company. 2017 organizational variations ${ }^{2}$. She further states that most Igbo sub-groups are organized along the lineage, clan and village affiliation. Traditionally, according to her, the Igbo practiced a quasi-democratic and republican system of government, founded on patrilineal system of descent known as umunna; made up of groups of related and extended families, who trace their relationships to a commonly known ancestor. Umunna is headed by the eldest male member of the extended family and villages are formed by a collection of different umunna. No wonder the prevalence of communal system of living in Igbo communities.

In Igbo musical arts, communal creativity or collaborative creativity is part of the musician's art and his audience (members of his community) is of great importance to him as well as his art. As he performs to entertain his audience, he is conscious of the fact that the success of his artistic creativity

2 Forchu, Ijeoma I." Igbo Musical Instruments: Socio-cultural tools for Sustainable Development" in Journal of Nigerian Music Education (JONMED). 2017. No.9. Pp 112-123. 
is highly dependent on the audience's (community) approval and acceptance. Therefore, the Igbo community's influence on the musical artiste and his art cannot be over emphasized; his singing, dancing, playing of instruments and costume put together. Whether these are still in existence or have been affected by some elements of modernity and more are some of the important facts this study tends to uncover. Digging deep into this involves a closer look at music in Igbo culture, the ohaka concept in Igbo musicology as well as technological advancements in modern Igbo musical practice.

\section{Theoretical Framework}

This study portrays/highlights experiences, issues and ideas based on the Igbo trado-philosophical concept of "Ohaka: The Community is Supreme." It then hinges on Adedeji's [3] "Transformative musicology" 3 theory which aims at the transformation of the environment and the World at large. It encompasses all musical activities that focus on transformative purposes; a product of intercultural musicology. It sets out to explore the possibilities of Ohaka concept, to harness and possibly utilize them for the achievement of transformative musicological goals. Information were gathered through personal experience as a performer, internet facilities and library sources

\section{Music in Igbo Culture}

Music in relation to Igbo culture has been discussed by several scholars and proven to be an integral part of Igbo culture which accompanies every average Igbo in one way or the other from cradle to grave. This expression - "cradle to grave " has also been explored by scholars, researchers and writers from diverse perspectives and presented in various guises like; "womb to tomb", "birth to death", "infancy till death", "through lifetime", "infancy to adulthood", "mortality stage", "beginning to end of life", and so on. Each of these expressions points to the simple fact that in Igbo culture, music lives in and with the people. In all Igbo activities, the role of music is obvious as there can hardly be any meaningful function without music. Music-making in Igbo functions/occasions "educates, informs, addresses issues, corrects impressions, directs people, heals, inspires, encourages, energizes, and criticizes and so on." Nzewi [4] informs that music is an ubiquitous social organiser as; it supervises the operation of established government; asserts in the maintenance of the laws of the land; safeguards and perpetuates tradition, discourages the degeneration of personal corporate morals; promotes social equity and fights injustice; crowns rulers, welcomes births, buries the dead, enforces public health programmes, generally organizes and

3 Femi Adedeji 'Intercultural Music as Agent of Transformative Musicology' in M. A Ortiz Molina and A. O. Fernandex. (eds.) Cultura, Culturas. Estudios Sobre Musica Y Education Intercultural. Granada; Grupo Editorial Universitario, (2006). 41-54 enlivens all purposes of communal get together. ${ }^{4}$

In the same vein, Nwamara [5] presents three basic musical-life-stages of the Igbo as "The Three Es;" which include "E1: Entrance and Early Life Stage, E2: Existence and Adulthood Stage, and E3: Exit and Funeral Rites Stage."5

\subsection{E1 (Entrance and Early Life Stage)}

Comprises of all the ceremonies that take place as soon as a new child is born up to the end of child rearing (i. e. from birth to the end of adolescent) are enumerated. These ceremonies and activities are accompanied by one kind of music or the other. These sub-stages with their corresponding songs that go in a sort of sequential order from birth to end of adolescent activity-related songs and their place in the life of the individual are as follows in a chronological order:

\subsubsection{Birth Announcement}

Birth announcement music is generally in form of ululation. In the Igbo culture, it is encoded in a number of loud and long hoots or calls made by the paternal grandmother or aunt. According to Okafor [6];

The sex of the baby is often not announced as a direct statement but encoded in reference to tools or trade depending on the prevalent occupation in the locality. For example, the palm-wine tapper's climbing rope (agbu-nkwu) or machete (mma olu) would refer to a male child while broom (azuza ezu/aziza ezi) or trading basket (aliaashua/ahia/afia) would refer to a female child. ${ }^{6}$

In some parts of Imo and Abia states, the sex of the child is mentioned in the birth announcement or proclamation of the child's birth in a kind of birth ululation called oro.

See an example below: OWE

Owei, Oweeeeeeeee X 2 Owei, Oweeeeeeee X 2

O muru gini, e? Delivered of what (gender)?

O muru nwanyi/nwoke Delivered of a baby-girl/babyboy

Here music plays the dual roles of information and education.

\subsubsection{Songs for Circumcision}

This usually takes place on the eight day of the male child's birth, with much merriment, music and dancing. One of the most popular songs for this occasion in Igbo culture is "Onuru akwa nwa" (whoever hears a baby's cry).

$\begin{array}{ll}\text { Onuru akwa nwa ee aaeeh! } & \text { Whoever hears the cry of a } \\ \text { baby (ee aaeeh!) } & \\ \text { Onye nuru akwa nwa me } & \text { Whoever hears the cry of a } \\ \text { ngwa ngwa, } & \text { baby make haste, } \\ \text { O bughi ofu onye nwe nwa } & \text { Baby belongs to all }\end{array}$

4 Meki Nzewi, Folk Music in Nigeria: A Communion. Journal of International Library of Africa, (1980) Vol. 6, No. 6. 6-21.

5 Alvan-Ikoku Nwamara, "Music in Nigerian Culture: From Womb to Tomb" in O. O. C. Uche and S. C. Okeke (Eds.) Nigerian History, Culture and SocioPolitical Development, (Enugu: John Jacobs, 2011), 87 - 97

6 Richard C. Okafor, Music in Nigerian Society. Enugu: New Generation Books. 2005. 
Music plays educative role in this case.

\subsubsection{Songs for Child Naming/Outing Ceremony}

This usually takes place on the twenty-eight day of a child's birth in Igbo culture. Activities include giving a name to the new born child, taking the child to various compounds/homes (mostly relations), market and the village square. In some modern Igbo societies, it takes place in a social gathering at the home of the child's parents where relations, friends and well-wishers gather to enjoy themselves amidst heavy music and dance. The major role of music here is entertainment.

\subsubsection{Lullabies}

This is a kind of song used by mothers and nannies to lull the baby to sleep or keep quiet. It is obtainable in large quantities in Igbo traditional culture. It also helps in preparing the mind of the child musically for future musical activities. This is an educative role. One of such songs is as follows:

$\begin{array}{ll}\begin{array}{l}\text { Onye muru nwa n'ebe } \\ \text { akwa? }\end{array} & \begin{array}{l}\text { Who is the mother of the crying } \\ \text { baby? }\end{array} \\ \begin{array}{l}\text { Egbe muru nwa n'ebe } \\ \text { akwa }\end{array} & \begin{array}{l}\text { The kite is the mother of the } \\ \text { crying baby }\end{array} \\ \text { Weta uziza weta ose } & \text { Bring spicy leaves, bring pepper } \\ \text { Weta ma ngororo ofe } & \text { Bring watery soup also } \\ \text { K'umu nnunu racha ya } & \text { For the birds to lick it } \\ \text { K'okpo tuutuu kpogbuo } & \text { Let hiccup kill them } \\ \text { ha } & \end{array}$

\subsubsection{Plaintive Songs}

In various Igbo homes, the employment of the services of housemaids abound. In some cases and for some reasons, these maids are so maltreated by their employers such that they always look very unhappy. In fact, unhappiness has become a trademark to some of them; and in such situations; they usually resort to singing songs that reflect their emotional state of mind and outbursts as a means of relief. This is an aspect where music plays some psychological/medical roles. Example of such songs includes:

$\begin{array}{ll}\text { Echuwe iyi Nda! } & \text { Time to fetch stream water, Nda! } \\ \text { Akpokue nwa enwe } & \text { They send for nwa enwe nne } \\ \text { nne, Nda! } & \text { (the motherless), Nda! } \\ \text { Akpawa nku, Nda! } & \text { Time to fetch firewood, Nda! } \\ \text { Akpokue nwa enwe } & \text { They send for nwa enwe nne } \\ \text { nne, Nda! } & \text { (the motherless), Nda! } \\ \text { Ebute nri, Nda! } & \text { Time to eat, Nda! } \\ \text { Achupu nwa enwe nne, } & \text { They pursue nwa enwe nne, } \\ \text { Nda! } & \text { Nda! } \\ \text { Nwa enwe nne, Nda! } & \text { Nwa enwe nne, Nda! } \\ \text { Ahushiela m anya, Nda! } & \text { I have suffered so much, Nda! }\end{array}$

\subsubsection{Cradle Songs}

Cradle songs are those songs sung to the baby-child in its early stage of life that serve as media of instruction. They go hand in hand with other activity songs sung consciously or unconsciously by the mother while washing in the stream, sweeping, playing music or dancing in her peer groups; all with the baby tied to its mother's back. The songs here are educative songs for the baby. So many songs belong to this sub-category.

\subsubsection{Games/Play Songs and Folktale Songs}

Igbo children usually take place in games and play songs as soon as they are able to sing. At this point they begin to function as active participants in the musical activities. The child begins by imitating the older children in their various games. Most of the game/play songs are performed at night with the moonlight as their stage light and the village square their stage. Little wonder why these games and their songs are referred to as moonlight games and moonlight songs respectively. Some of the songs involved here include folktale songs, wrestling songs, oga game song, swell song, hide and seek game song, ring games like okereke, okereke and akpankolo songs and so on. Roles of music here include educative, critical, recreational and entertainment. Okereke Okereke goes thus:

$\begin{array}{ll}\text { Okereke, Okereke, dududu } & \text { Okereke, Okereke, dududu } \\ \text { ya ya } & \text { ya ya } \\ \text { Okorafo, Okorafo, dududu ya } & \text { Okorafo, Okorafo, dududu } \\ \text { ya } & \text { ya ya } \\ \text { Kwe na oga na aga, O ga na- } & \begin{array}{l}\text { Respond that it has to go } \\ \text { turn by turn. }\end{array}\end{array}$

\subsubsection{Children Peer Groups Songs and Dances}

The songs and dances here are rehearsed over a period of time before they are presented formally to the community at the village square. The dances are usually stylized in a way that depicts the people's ways of life, popular activities or occupations. For instance; farming and fishing are reflected in some of such dances. Roles of music in this case are mainly educative and recreational.

\subsubsection{Work Songs}

Songs are used here to release the tedium or stress of the work being done. Most of the songs are sung a cappella while some are accompanied with musical instruments and/or work tools. Example includes the following:

$\begin{array}{ll}\text { Ayi na-ako ede, } & \text { We are planting cocoyam } \\ \text { Ede mara nma okuko } & \text { Cocoyam is good for planting }\end{array}$

Several work songs abound in Igbo culture and most importantly, at this stage in a child's life, he is gradually leaving adolescent to adulthood therefore, his/her musical activities begins to tilt towards the next stage - the E2, which has to do with adulthood. Music here energizes and encourages which are aspects of psychological functions of music.

\subsection{E2 = Existence and Adulthood Stage}

At this stage of musical life of the Igbo, though work songs still exist, other more serious musical activities also occupy the life of the individual. There are certain 
"seemingly mandatory" social responsibilities or better still challenges that will come the individual's way at this stage of life. The person is expected to join certain cults or traditional institutions, get married, register with his age grade and participate in their activities as well as village and town's meetings. In some cases, especially when the individual is wealthy, he is at a later stage expected to take chieftaincy titles. All these activities have certain music and sometimes dances that go with them as follows:

\subsubsection{Initiation Songs}

This includes all songs that are exclusive to particular cult groups. They are learnt and performed by the group at their initiations ceremonies. Some are to be sung by the initiates while others are for the initiated members and their leaders. Some of the songs are chanted and responded to while others are sung; sometimes also in call and response form. A typical example is the spirit-manifest (mmuo/mmanwu/mmonwu) cult songs. This exists in Igbo culture and their songs are mostly satirical and corrective.

\subsubsection{War Songs}

In this category are energetic songs that are capable of instigating one into action. The young men are mainly involved in this kind of singing. The lyrics contain warnings, praises (for themselves, their warriors and their community), encouragement, loyalty and patriotism. They are patriotic songs generally. Example of such songs is:

Onye akpakwana agu aka n'odu,

Ma o di ndu, ma o nwuru anwu

Let no one touch the lions tail

Whether the lion is alive or dead

\subsubsection{Age-Grade Songs}

Age-grade songs include both the songs such groups sing in their meetings either for their group relaxation or entertainment and the songs they learn specifically for outings - burials, marriages, festivals etc. The second category is similar to that of the peer group music and dance but this time in a more matured and advanced manner. Their songs are educative and entertaining.

\subsubsection{Festival and Feast Songs}

This includes all the songs that are used in celebrating special festivals in communities. In Igbo communities, Okafor [7] observes that the Igbo year (aro) is a round of festivals and ceremonies, which vibrate with life, colour, sounds and meaning. He went further to state that it is music that gives character to Igbo festivals such that an Igbo would say that a festival is "warm" - olili kpolu oku - when it has a lot of singing and dancing. Such festivals and feast provide avenue for age groups and other classified groups to meet and build or strengthen effective and lasting friendships. They encourage sociability by serving as cultural vehicles for encouraging team work. Music here entertains, educates and

7 Richard Okafor, "Women in Igbo Musical Culture". The Nigerian Field. (1989). (54) $133-140$. unifies.

\subsubsection{Marriage Songs}

Marriage in Igbo culture is usually a business of one family and another and not just that of the two individuals who wish to get married to each other. It therefore brings many people and groups together and consequently creates room for merry-making and a lot of singing and dancing. In some cases in modern times and if affordable (as a means of showcasing wealth), different groups of musicians are invited and even some uninvited musicians also participate in supplying music for the event. Some of the songs are songs of advice, jubilations, praise and prayers for the couple.

O laa, o laa be ya! She has gone, she has gone to her
home
O laa, o laa be ya! She has gone, she has gone to her
home

\subsubsection{Title-taking Songs}

In title-taking, musical activities are as heavy as that of marriage ceremonies. The only major difference is in the lyrical content of the songs. In marriage, the songs address marriage issues, while in title-taking; the songs address titletaking and general cultural issues.

Note: At this stage in a person's musical-life-stage, there is usually a repeat of events from the beginning but this time in an "extended personality manner". This is when the individual involved gets married and he/she is blessed with a child. The child begins the cycle from the beginning with the parents not in isolation. They also take part from the beginning but this time as passive participants (extended personality) until they are old and die of old age, sickness or accident and move to the next stage (E3). This is the irony of life.

\subsection{E3 = Exit and Funeral Rites Stage}

Death is an inevitable end to every mortal although most people do not like to discuss it not to think of having anything to do with it. When one dies and is lucky to have people around to bury him/her, the Igbo people usually perform some funeral rites according to the person's religious beliefs or traditional customs. Igbos burial/funeral songs are uncountable. In modern times, concerts are even being organised for the dead where groups are invited from far and near to grace the occasion. The level of music making in funerals depends on the societal class of the person that passes on; the person's age, wealth or class and position in the society. These determine whether the occasion will be "cold" or "warm". Music here plays several roles ranging from educative and entertainment to psychological and religious roles. This is the end of the journey from womb to tomb.

In each of these life-long activity-related-songs, the community is involved in one way or the other. It is difficult to alienate the community in musical activities in Igbo tradition. Therefore it becomes pertinent at this point in this discussion, to take a look at the relationship between the 
community and music-making in Igbo traditional communities. Take for instance in E1: Birth Announcement songs, Songs for Circumcision, Songs for Child Naming/Outing Ceremony, Games/Play Songs and Folktale songs, Children Peer Groups Songs and Dances, Work Songs; all belong to the community-based songs. They are performed by the members of the larger community; most times without rehearsals or prior notice and information. So they are mainly impromptu performed and basically by members of community themselves. Lullabies, Plaintive Songs and Cradle Songs are performed by the individuals concerned but must fall within certain culturally acceptable norms, the fact notwithstanding that they are solos performed within their independent homes.

Stage two which is E2 (Existence and Adulthood Stage), houses Initiation Songs, War Songs, Age-Grade Songs, Festival and Feast Songs, Marriage songs and Title-taking Songs. All these are usually done by members of the community. In some cases, specialized musical groups are invited where such can be afforded; and in such cases, this musician is guided by what is acceptable to the community and the culture and traditions of his people. The artiste needs the approval of his kind of music by his people.

In death, which is the final stage E3 (Exit and Funeral Rites Stage), the situation is not different from what is obtainable in stage E2. Community decides what must be their acceptable form of music and what would not be acceptable to them as a people with a particular culture and laid down legacies and traditions that need to be protected. The community is supreme.

\section{The Musician in Igbo Community}

Music in Igbo community is usually a social event. Such social events may include recreation, rituals, ceremonies, festivals or even works that are done collectively; like clearing paths, building bridges, town halls, search party, and so on. Nketia [8] observes that: those who get together in such communal activities generally belong to the same ethnic or linguistic group. The basis of association for music making, however, is usually the community, those members of the ethnic group who share a common habitat (such as a group of homesteads, a village, a town, or a section of a town) and who live some kind of corporate life based on common institutions, common local traditions, and common beliefs and values. $^{8}$

They have a strong social bond not only because that they know each other; but they may be related as well as share a lot in common. Music for them is community based as it serves as a medium of sharing communal creative experience as well as avenue for group sentimental expression. This does not in any way suggest that individualized music making does not exist in Igbo culture. It does; either for selfenjoyment or for others' and in some cases for ritual or worship.

8 Kwabena Nketia, Music of Africa. (New York: W. W. Norton, 1974).
The Igbo musician is one who is considered a good performer; either a good singer (good voice and good memory), a good dancer or a good instrumentalist (flutist, drummer etc). Other qualities include good ear, being dramatic on stage, ability to compose or create music, ability to concentrate, ability to be sensitive or show a general awareness of current situations, clarity of mind and so on. In addition to all these, he/she must be at home with the oral literature and history of his community. This is the most important attribute because lack of such knowledge would result to performing out of context or lead to actions considered a taboo in his community out of ignorance. Satisfying the community is the musician's primary concern in all his artistic creativity. If he fails to convince the community of his mastery or artistic capabilities, he is considered a failure; therefore the community remains supreme in the world of traditional Igbo musical arts and entertainment in general. The musician's art is greatly influenced by his community and this certifies the supremacy of the community (ohaka) in Igbo musical arts practice.

\section{The Issue of Ohaka Concept in/and Igbo Musicianship}

The "Ohaka" concept remains one of the most cherished values of the Igbo as it has a place in all spheres of life; music inclusive. Little wonder why there commonly exist in Igbo culture, as I mentioned earlier, names like; Nwoha/Nwora (Community-Owned Child), Oranekwulu/Ohanekwulu (Community Intercedes/intervenes), Ohaka/Oraka (Community is Supreme), Ohabuike/Orabuike (Community is Strength), Orajiuka/Ohajiuka (Community Decides). Others include Obiora/Obioha (Community-Owned Son), Adaora/Adaoha (Community-Owned Daughter), Ohawughiro/Ohabughiro (Community is no enemy), Ohanyere/Oranyelu (Given by Community), Ohabuogwu/Orabuogwu (Community is medicine), Ohadiegwu/Oradiegwu (Community/people is/are awesome), Ohadike/Oradike (Brave/strong man of the community), Ohadinma/Oradinma (Community is useful), Ohadoo/Oradoo (I plead with the people), Ohaekeyi/Oraekei (Community has apportioned), Ohaekwusi/Oraekwusi (Community has decided), Ohaeri/Oraeri (One that cannot be harmed by the community), Ohaeto/Oraeto (Man of the community), Ohagwu/Oragwu (community never vanishes), Ohajiuba/Orajiuba (Community holds wealth), Ohakamadu/Orakamadu (Community is more important/powerful than an individual), Ohanu/Oranu (Let the community hear), Ohazom/Orazom, (Let the community protect me), Ohakim/Orakim (Community mandate), Ohanyeaka/Orannyeaka (Community Help), Dikeoha/Dikeora (Community Warrior), and so on. These names go a long way to indicate or signify the value attached to Ora/Oha (Community) in Igbo culture. There are others that do not necessarily go with the prefix or surfix of "Oha/Ora" yet they amplify and encourage the Ohaka philosophy. Some of such names are: Umunnawuike/Umunnabuike (Kindred is strength), Igwedimma 
(Multitude is Good) In the same vein, there exist names that discourage individualism; such names include; Otuadinma, Ibuadinma, Somadina, Naanimebina, Dibua, and so on.

A lot is attached to names given to Igbo people as opposed to the Western world that uses one's name as just a tag or brand to distinguish him/her from other individuals. To the Igbo, it is a more serious issue; it is often believed that some authentic Igbo names carry prophetic potency such that those who bear them often grow to be or act in line with his/her name. There exists much philosophy, education, spirituality and mystery surrounding Igbo name-giving and name-taking. A well thought out Igbo name tells so much about the parents' or clan's remote history, their present circumstances or even their hopes and aspirations. Therefore, Igbo people do not joke with name-giving or name-taking but take their time to decide what names to take or give; bearing in mind that they have meanings, implications and effects. Okafor [9] informs that;

Igbo names are not mere tags of identity or appellations but very deep expressions of attitudes, sentiments, aspirations and commentaries on life experiences. Igbo names give identity. The name of a person is the expression of his individuality and his possession...most Igbo names cannot be fully appreciated without adequate knowledge of the Igbo worldview. $^{9}$

In the area of music, the cultivation of musical life in traditional Igbo society is achieved through active participation in group life. Music making in Igbo communities is basically in form of community experience. The individual is important but cannot function without the community. Continuity in Igbo musical arts, in a broader sense, depends greatly on both individual and group efforts; the creative individual creates the basis while those who learn it and perform it in social occasions sustain the tradition. The Igbo musical artiste performs in and for his community and his art is guided by the norms and values of his culture. He co-performs and collaborates with gifted members of his community as well as requires the approval of his community in terms of what to do/perform and what not to do/perform.

The musician in most cases makes use of some musical instruments to perform his music and sometimes in addition to voice. Chukwu [10] defines musical instruments as:

Humanly designed and constructed mechanisms which when struck, bowed, plucked, blown or touched (depending on the pressure exerted on such instrument), produce certain sounds that are generally accepted by the makers and users of such instrument(s). ${ }^{10}$

This implies that the sounds need to be accepted by the makers and users of these instruments before it becomes an instrument for such people. Therefore the musician's musical instrument would be constructed by members of his

9 Richard Okafor, Lawrence Emeka and Tom. Inyiama., Igbo Personal and Title Names. Enugu: New Generation Books. 2008.

10 Sam K. I. Chukwu, Igbo Musical Instruments: A Taxonomical Study on the Classification of Traditional Musical Instruments of Imo State. Unpublished $\mathrm{PhD}$. Dissertation, Nnamdi Azikiwe University, Awka. 2007. community in this case and would require their approval as well. His costume is not left out as it would also require community approval and acceptability.

The most important and commendable aspect of this concept is that it ensures some degree of social control in Igbo musical practice and activities. For instance, music for a rite may not be freely performed in another context without questioning by the members of the community. In the same vein, some musical instruments that are classified; either by virtue of sex, age, class or religion, may not be allowed to be used for other inferior purposes. The "Ohaka" concept (where the community is regarded as supreme) is superior to "Ikeotuonye" (where an individual is regarded as most powerful - may be as a result of political connection or in most cases in recent times, wealth).

Ikeotuonye syndrome has become and remains the major problem of the Igbo nation today. The Delta-Igbo people bear the name "Nkeonyeasoa" (meaning that one is always content or full of praise of his/her deeds). It is obvious that no one fails an examination he/she sets for himself/herself. This syndrome of self-centeredness destroys all aspects of Igbo socio-cultural existence. Music has been affected so negatively by this syndrome and things do not even seem to be getting better as the days go by. We need a general change of attitude from Ikeotuonye to Ohaka.

\section{Modernism and Its Influences on Ohaka Concept in Igbo Musical Practice}

In recent times, modernity has not been so friendly to this "Ohaka" concept. Globalization has been the strongest enemy of this concept. Idolor [11] informs that globalization is "the integration of the activities of various people irrespective of distance and national boundaries." ${ }^{11}$ He notes that globalization creates a pool of ideas and opportunities that facilitate understanding, cooperation and interdependence amongst sovereign states through new information, communication, transportation and technological applications...." He further states that "as a phenomenon, globalization is an imposing development that can hardly be resisted by any society that operates communication network."

It is then as a result of this that one finds it difficult to control what happens around his or her socio-cultural environment. The internet has made it easy for information to get to everyone at a very little space of time. Ohaka has less power over what is happening here or there. Regulation has become extremely difficult if not impossible.

Musically speaking, globalization has divested Igbo music its spiritual, healing, humanizing and moral roles it used to possess. Those who have the opportunity of advertising Igbo

11 Emurobome Idolor, "Strategizing Globalisation for the Advancement of African Music Identity," A Paper Delivered at the International Conference on African Arts at the Delta State University, Abraka, 10th -14th November 2004. 
music internationally do not consider the actual Igbo music as important; rather they go for the bastardized versions of the music without having a good knowledge of what the Igbo music is. Of course, the Ohaka concept has no or very little significant role to play here as a wider audience is involved as well as ill-informed and mixed cultural audience is involved in this case. Nudity and sex related and immoral texts have become the order of the day in modern Igbo musical video/audio that is marketed in the international music market. Does this mean that the very music that makes the Igbo what he is has gone?

Another side to this is the issue of computer-aided performance. The computer serves as a multi-instrumentalist as well as plays the role of a full orchestra. When this is possible, where does the group come in? One-man show is preferred to group performance due to its relative low cost. The present trend is to invite a singer and supply a sound track with the help of a disc joker (DJ) and the performance is on. Igbo musicians have taken to hip-hop; which is the genre in vogue (not minding that they are using materials from the traditional Igbo music). Today's Naija hip-hop is a fusion of traditional Igbo music and dance band instrumental accompaniment; yet most of the Igbo people (especially the youths) do not value Igbo traditional music but praise hiphop. I am not against hip-hop but the trend and attitude of our contemporary musicians and those who patronise them pose a major problem to the traditional Igbo musical arts culture. Its future is at stake.

The marketers on the other hand, are not helping matters. They would insist on what they want, which does not conform to the standards or ethics of Igbo musical practice. They go for what the public wants. This public has no or little cultural knowledge of the Igbo and has nothing positive in mind for the Igbo race. Shall the Igbos continue like this? What shall be done about this ugly situation?

\section{The Way Forward}

Things have really fallen apart; even worse than Chinua Achebe [12] saw it when he wrote the novel - Things fall Apart. ${ }^{12}$ Therefore there is need for all stake holders to wake up and hold the bull by the horn to fight this cankerworm eating deep into the very fabrics of Igbo's existence as a people/nation. In form of suggestions, I present the following:

(1) There is the need to incorporate the service of the local musicians into the academic programme of institutions of higher learning where music and music related courses are thought (especially those in Igbo states).

(2) Igbo musical arts and culture need to be given more boosting in international events and activities. This can be achieved by encouraging the practitioners in the little they have achieved and support those who wish to venture into such projects and activities in future.

(3) Associations like the Otu Subakwa-Igbo and Igbo

12 Chinua Achebe, Things Fall Apart (London: Heinemann, 1958)
Studies Association should take up collaborative projects with music institutions in Igbo land that have plans for the propagation of Igbo music and culture.

(4) More collaborative works should be encouraged in the area of Igbo music as well as linkages with necessary bodies to promote the actual Igbo music and culture to take over from the bastardized ones that fill every nook and cranny of the global entertainment market.

(5) Sponsorship of Igbo music oriented projects should be encouraged as well as opportunities for studies and practical experiences for young scholars and practitioners respectively.

(6) Professionalism, training and practicality should always be put into consideration when consultations and appointments are made in music related issues. This will ensure putting the round peg in a round hole that vice versa.

(7) More attention should be paid to the internet music market to ensure moderation and regulation of the Igbo music in the global market.

(8) In the staff recruitment of music and other related arts regulatory bodies in Nigeria, balanced cultural background and knowledge should be considered and most importantly incorporated as one of the criteria for employment.

(9) Finally and most importantly, there is need for scholars and researchers to redirect their research interests towards implementation of already researched projects than looking for new ways to problems that solutions have been proffered for long ago. Research studies should be guided by what Nwamara and Chukwu [13] branded Retrieval Research Strategy (RRS), which entails "the systematic retrieval of all research works on Nigerian/African musicology from institutions, libraries, shelves etc., and looking into them in order to utilize and implement the observations, suggestions and recommendations thereof" 13 . A FOUR-WAY APPROACH was recommended for the realization of RRS as follows; I: Data Discovery and Retrieval, II: Data Collation, Compilation and Packaging, III: Advertising, Popularizing and Marketing, IV: Implementation.

These and more are few ways of tackling the problem at hand. Ohaka is an important concept to the Igbo and should not be allowed to slip off the hands of the Igbo people. It is their heritage; and therefore should be guarded jealously; never to allow Ikeotutonye to swallow the Igbo out of greed and quest for insatiable power for self-aggrandizement. Remember Mbiti's quote that "I am, because we are; and since we are, therefore I am." ${ }^{14}$ Mbiti [14].

13 Alvan-Ikoku Nwamara \& Sam Chukwu, "The Retrieval Research Strategy (RRS): A Recapitulation on Music Studies' Research Findings in Afric". Unpublished paper presented at the PASMAE (ISME-African Region) Conference held at the University of Botswana in Gaborone, Botswana, 26th 30th July 2011.

14 J. S. Mbiti, African Religions and Philosophy. (New York: Doubleday 1970) 141. 


\section{Conclusion}

The collapse of the Ohaka concept in Igbo culture and philosophy is not peculiar to music but has affected all spheres of the Igbo life and existence. It is a major problem which needs to be addressed and subsequently faced squarely with actions. It cuts across the religious, social, political, economic, geographical, musical and artistic lives of Igbo people. Money has become the centre of all that controls most Igbo minds in recent times. And this is gradually taking over the minds' set of the young. If allowed to continue, there might not be any Igbo culture in the nearest future. Money would become the interest of all that nothing would move anymore. The kingship will be bought with money, all things will be monetized and things will not only fall apart but broken completely. There will be total collapse in all life activities and no one would be able to trace his or her root anymore.

To avoid all these, now is the time to speak up and destroy this deadly monster that is threatening the Igbo peaceful existence and gradually becoming a culture. Say no to nonIgbo traditions and culture that are threatening the Igbo and embrace Igbo dignified customs and values for a better Igbo nation. Posterity will remember those who would take the bull by the horn and make things right at this time.

\section{References}

[1] Okafor, R. C. A Study of Igbo Folk Songs. Enugu: Academic Publishing Company. 2017.

[2] Forchu, Ijeoma I." Igbo Musical Instruments: Socio-cultural tools for Sustainable Development" in Journal of Nigerian Music Education (JONMED). 2017. No.9. Pp 112-123.

[3] Adedeji, F. "Intercultural Music as Agent of Transformative Musicology" in M. A Ortiz Molina and A. O. Fernandex. (eds.) Cultura, Culturas. Estudios Sobre Musica Y Education
Intercultural. Granada; Grupo Editorial Universitario, (2006). 41-54.

[4] Nzewi, M. "Folk Music in Nigeria: A Communion". Journal of International Library of Africa, 1980, Vol. 6, No. 6. Pp $6-$ 21.

[5] Nwamara, A. O. Music in Nigerian Culture: From Womb to Tomb in O. O. C. Uche and S. C. Okeke (Eds.) Nigerian History, Culture and Socio-Political Development. Enugu: John Jacobs 2011, 87-97.

[6] Okafor, R. C. Music in Nigerian Society. Enugu: New Generation Books. 2005.

[7] Okafor, R. C. "Women in Igbo Musical Culture". The Nigerian Field. (1989). (54) 133 - 140.

[8] Nketia K. Music of Africa. New York: W. W. Norton, 1974.

[9] Okafor, R. C., Emeka L. and Inyiama T., Igbo Personal and Title Names. Enugu: New Generation Books. 2008.

[10] Chukwu, S. K. I. Igbo Musical Instruments: A Taxonomical Study on the Classification of Traditional Musical Instruments of Imo State. Unpublished PhD. Dissertation, Nnamdi Azikiwe University, Awka. 2007.

[11] Idolor, Emurobome. "Strategizing Globalisation for the Advancement of African Music Identity," A Paper Delivered at the International Conference on African Arts at the Delta State University, Abraka, 10th-14th November 2004.

[12] Achebe, C. Things Fall Apart. London: Heinemann, 1958.

[13] Nwamara A. O. \& Chukwu S. K. I. 'The Retrieval Research Strategy (RRS): A Recapitulation on Music Studies' Research Findings in Africa'. Unpublished paper presented at the PASMAE (ISME-African Region) Conference held at the University of Botswana in Gaborone, Botswana, 26th -30th July 2011.

[14] Mbiti, J. S. African Religions and Philosophy. New York: Doubleday. 1970. 